\title{
MODIFIED CEMENT-BASED MORTARS: CRACK INITIATION AND VOLUME CHANGES
}

\author{
MODIFICIRANE MALTE NA OSNOVI CEMENTA: INICIACIJA \\ RAZPOK IN VOLUMENSKE SPREMEMBE
}

\author{
Ivana Havlikova ${ }^{1}$, Vlastimil Bilek Jr. ${ }^{2}$, Libor Topolar ${ }^{1}$, Hana Simonova ${ }^{1}$, \\ Pavel Schmid ${ }^{1}$, Zbynek Kersner ${ }^{1}$ \\ ${ }^{1}$ Brno University of Technology, Faculty of Civil Engineering, Veveri 331/95, 60200 Brno, Czech Republic \\ ${ }^{2}$ Ditto, Faculty of Chemistry, Purkynova 464/118, 61200 Brno, Czech Republic \\ havlikova.i@fce.vutbr.cz \\ Prejem rokopisa - received: 2014-08-05; sprejem za objavo - accepted for publication: 2014-09-18
}

doi:10.17222/mit.2014.179

\begin{abstract}
The aim of this paper was to quantify the crack initiation and volume changes of three types of fine-grain cement-based composites: the reference one including Portland cement only and the other two with the mass fraction $20 \%$ of Portland cement replaced by granulated blast-furnace slag or pulverized-coal fly ash. Half of the specimens from each mixture were cured according to ASTM C1260-94 and ASTM C1567-07, other specimens were cured in water. The length changes were measured during the curing (a test for the risk of the alkali-silica reactivity). Furthermore, a three-point-bending test was performed on these specimens to obtain the fracture parameters, which were determined using a double- $K$ fracture model. It was found that the type of specimen curing has a significant effect on the volume changes and a moderate influence on the elasticity modulus, the crack initiation and fracture-toughness values.
\end{abstract}

Keywords: cement-based composite, slag, fly ash, alkali-silica reaction, crack initiation, double- $K$ fracture model

Namen tega članka je oceniti iniciacijo razpoke in spremembe volumna treh vrst drobnozrnatih kompozitov na osnovi cementa: osnovna samo s cementom Portland, pri drugih dveh je bil masni delež $20 \%$ cementa Portland nadomeščen $\mathrm{z}$ granulirano plavžno žlindro ali s prahom elektrofiltrskega pepela premoga. Polovica vzorcev iz vsake mešanice je bila strjena skladno z ASTM C1260-94 in ASTM C1567-07, drugi vzorci so bili strjeni v vodi. Med strjevanjem je bilo merjeno spreminjanje dolžine (preizkus za rizik reaktivnosti alkalija-silicijev dioksid). Poleg tega je bil izvršen pri teh vzorcih tritočkovni upogibni preizkus, da bi dobili parameter preloma, kar je bilo določeno z uporabo lomnega modela z dvojnim $K$. Ugotovljeno je bilo, da ima način strjevanja vzorcev močan vpliv na spremembe volumna in zmeren vpliv na modul elastičnosti, na iniciacijo razpoke, kot tudi na vrednosti lomne žilavosti.

Ključne besede: kompozit na osnovi cementa, žlindra, leteči pepel, reakcija med alkalijami in silicijevim dioksidom, iniciacija razpoke, lomni model z dvojnim $K$

\section{INTRODUCTION}

The utilization of supplementary cementing materials (SCM) in the Portland-cement-based composite manufacturing is a current topic in materials engineering. Besides the ecological and financial aspects, it also allows us to improve the mechanical properties and durability of a composite. One of the main durability problems is the risk of an alkali-silica reaction (ASR). ASR can be very harmful to a concrete construction because it is accompanied by a significant volume expansion. As a consequence, deleterious cracking of the aggregate and the binder phase can develop, leading even to a failure of the concrete structure. ASR can be suppressed through several ways, but some of them are impractical or expensive, such as the choice of non-alkali-reactive aggregates, restriction of the access of moisture to the concrete mass or the use of ASR inhibitors ${ }^{1}$. From this point of view, a very suitable possibility of ASR mitigation can be the use of SCM, which is also the topic of this paper.

In this paper, the authors examine the effect of replacing $20 \%$ of the mass of Portland cement (PC) in a fine-grained composite by selected admixtures on mechanical-fracture-parameter values and volume changes. The used admixtures are granulated blast-furnace slag and pulverized coal fly ash. Specimens of three different mixtures were prepared and, for comparison, two types of curing were used - the first one according to ASTM C1260-94 ${ }^{2}$ and ASTM C1567-07³, while the second one was performed in water. Length changes were measured to assess the effect of the admixtures on the suppression of ASR during this process. The result of the lengthchange measurement is the relative expansion at the age of $16 \mathrm{~d}$.

The values of the mechanical-fracture parameters of quasi-brittle materials are usually determined via an evaluation of the records of the experiments on specimens with stress concentrators. In this paper, three-point-bending fracture tests were conducted on the above-mentioned specimens, which were evaluated using a double- $K$ fracture model ${ }^{4}$. The advantage of this model is that it describes different levels of crack propagation: the initiation which corresponds with the beginning of a stable crack growth (at the level where the stress inten- 
sity factor $K_{\mathrm{Ic}}^{\text {ini }}$ is reached) and the part featuring an unstable crack propagation (after the unstable-fracture toughness $K_{\text {Ic }}{ }^{\text {un }}$ has been reached). The results obtained with the double- $K$ model are the modulus of elasticity, the fracture toughness and the relative resistance to stable crack propagation.

\section{EXPERIMENTAL PART}

\subsection{Materials and specimen preparation}

Specimens with the nominal dimensions of $25 \mathrm{~mm} \times$ $25 \mathrm{~mm} \times 285 \mathrm{~mm}$ were prepared from three types of mixture. The first mixture was the reference $(\mathrm{R})$, thus containing one part of PC CEM I 52.5 R to 2.25 parts of natural sand $(0-4 \mathrm{~mm})$ by mass. In the other two mixtures $20 \%$ of PC was replaced with granulated blast-furnace slag (S) or pulverized-coal fly ash (F). All these admixtures originated from Czech plants. The water-tobinder ratio was 0.47 for all the mixtures. A total of 18 beams were prepared, thus, six specimens from each type of mixture.

\subsection{Curing of specimens and the measuring of length changes}

The specimens were cured and their length changes measured according to ASTM C1260-94 and ASTM C1567-07. The specimens were demolded $24 \mathrm{~h}$ after the mixing, fitted with gages and stored in tap water of 80 ${ }^{\circ} \mathrm{C}$ for another $24 \mathrm{~h}$. Then a zero reading of the specimen length compared to the reference rod was taken. After this, a half of the total number of the specimens, i.e., three specimens from each mixture were cured for $14 \mathrm{~d}$ at $80{ }^{\circ} \mathrm{C}$ in a $1-\mathrm{N}$ sodium hydroxide solution $(\mathrm{H})$. For comparison, other specimens were cured for the same time in water (W) of the same temperature. To illustrate, Figure 1 shows the classification and designation of the specimens by mixture and their curing conditions.

The relative length changes (in \%) of the specimens were recorded during both types of curing and subtracted each workday. The relative expansion of the specimens

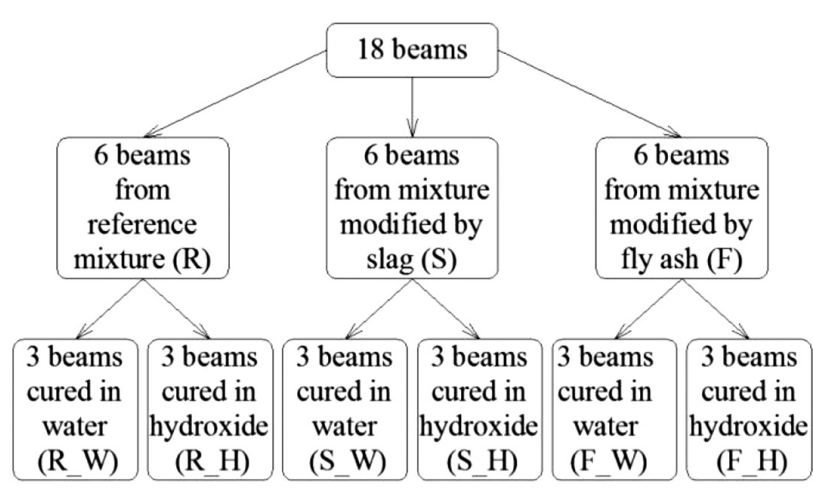

Figure 1: Classification of the specimens by mixture and curing condition

Slika 1: Delitev vzorcev po mešanicah in razmerah pri strjevanju for the total age of $16 \mathrm{~d} \varepsilon_{16 \mathrm{~d}}$, was calculated using the following relation:

$$
\varepsilon_{16 \mathrm{~d}}=\frac{\Delta l-\Delta l_{0}}{l_{k}} \cdot 100(\%)
$$

where $\Delta l$ is the specimen length compared to the reference rod for the age of $16 \mathrm{~d}$ in $\mathrm{mm}, \Delta l_{0}$ is the specimen length compared to the reference rod at the zero reading in $\mathrm{mm}$, and $l_{\mathrm{k}}$ is the effective gage length in $\mathrm{mm}$ (generally $l_{\mathrm{k}}=250 \mathrm{~mm}$ ).

\subsection{Fracture tests}

A quantification of the mechanical fracture parameters was performed using tests on the specimens with stress concentrators. In this paper, three-point-bending tests were performed on the beams with a central-edge notch. The geometry of a specimen used in this test is shown in Figure 2, where $D$ is the specimen depth, $B$ is the width, $L$ is the length, $S$ is the span, $a_{0}$ is the initial notch length, $H_{0}$ is the thickness of the edge of the holder clip on the extensometer (for all the specimens $H_{0}=2.5$ $\mathrm{mm}$ ) and $C M O D$ is the crack-mouth-opening displacement at load $P$. In this case, the specimens were cut from

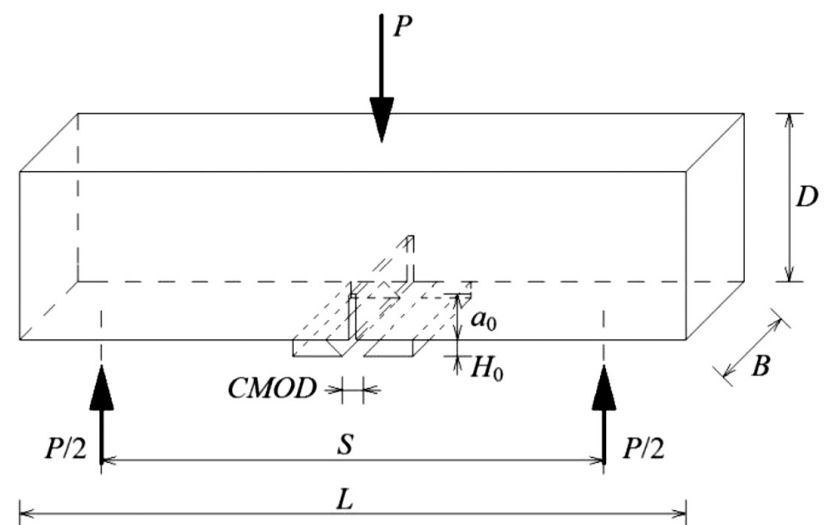

Figure 2: Three-point-bending-fracture test geometry Slika 2: Geometrija tritočkovnega upogibnega preloma

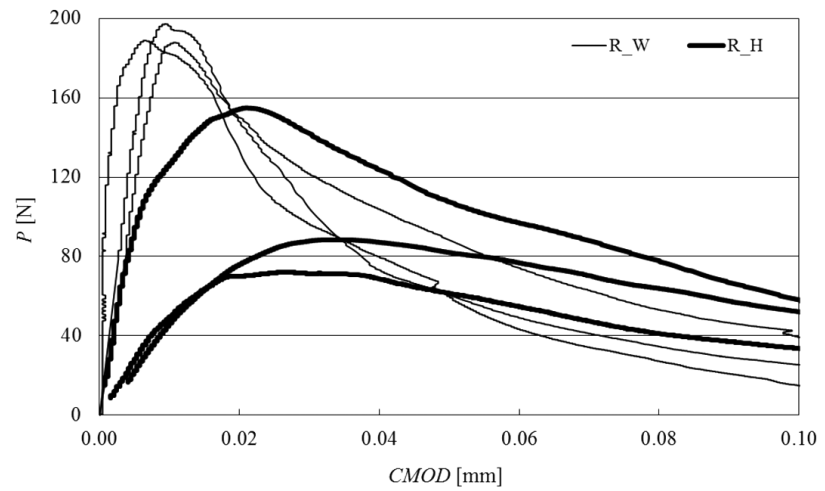

Figure 3: $P-C M O D$ diagrams recorded during testing - the reference set

Slika 3: Diagrami $P-C M O D$, posneti med preizkušanjem - referenčna vrsta 


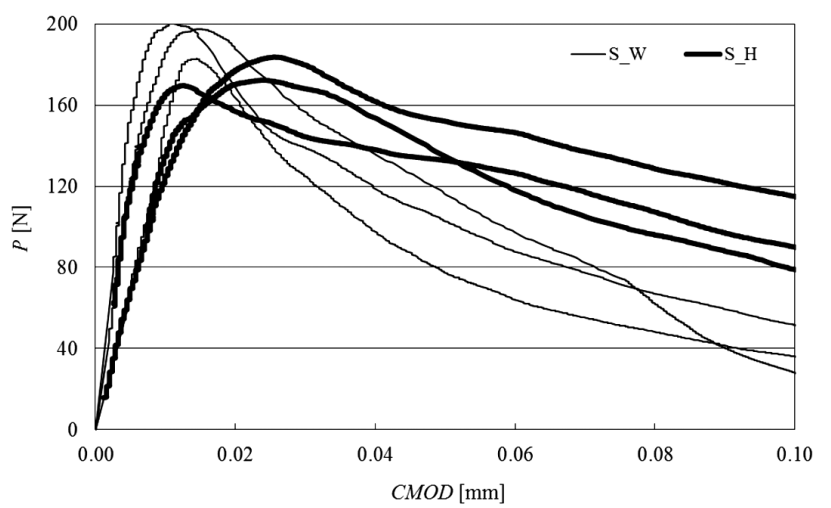

Figure 4: $P-C M O D$ diagrams recorded during testing - the set of specimens with blast-furnace slag $(\mathrm{S})$

Slika 4: Diagrami $P-C M O D$, posneti med preizkušanjem - vrsta vzorcev s plavžno žlindro $(\mathrm{S})$

the original beams, the nominal dimensions of the specimens were $25 \mathrm{~mm} \times 25 \mathrm{~mm} \times 200 \mathrm{~mm}$ and the span length was $150 \mathrm{~mm}$. The initial notch was made with a diamond-blade saw. Note that the depth of the notches was about $1 / 3$ of the specimen depth. The specimen age was $28 \mathrm{~d}$. Fracture tests were carried out using a Heckert FP 10/1 testing machine within a range of 0-400 N.

Load-versus-crack-mouth-opening-displacement $(P$ $C M O D$ ) diagrams were recorded during the tests (Figure 3 for R, Figure 4 for the specimens of the mixture modified with $\mathrm{S}$ and Figure $\mathbf{5}$ for the specimens with $\mathrm{F}$ ). From these diagrams we deducted the input data for the double- $K$ fracture model (Figure 6), namely, the maximum load $P_{\max }$ and its corresponding critical crackmouth-opening displacement $C M O D_{\mathrm{c}}$, and load $P_{i}$ deducted from the linear part of a diagram and its corresponding crack-mouth-opening displacement $C M O D_{i}$.

\subsection{Double-K fracture model}

In principle, a double- $K$ fracture model ${ }^{4}$ combines the concept of cohesive forces acting on the faces of cracks during a fictitious (effective) crack increment with the criterion based on the stress-intensity factor.

As previously mentioned, the $P-C M O D$ diagrams were used to determine the fracture parameters of the double- $K$ model. In this case, the unstable fracture toughness $K_{\text {Ic }}^{\text {un }}$ was the first to be numerically determined, followed by a determination of the cohesive fracture toughness $K_{\mathrm{Ic}}{ }^{\mathrm{c}}$. When both of these values were known, the following formula was used to calculate the initiation fracture toughness $K_{\mathrm{Ic}}{ }^{\text {ini: }}$ :

$$
K_{\mathrm{Ic}}{ }^{\text {ini }}=K_{\mathrm{Ic}}{ }^{\text {un }}-K_{\mathrm{Ic}}{ }^{\mathrm{c}}
$$

Details regarding the calculation of both the unstable and cohesive fracture toughness can be found in numerous sources ${ }^{5,6}$.

To determine the cohesive part of the fracture toughness $K_{\mathrm{Ic}}{ }^{\mathrm{c}}$ it is necessary to accept the assumption of the distribution of the cohesive stress $\sigma$ along the fictitious crack. Generally, in a cohesive crack model, the relation between the cohesive stress $\sigma$ and the effective crackopening displacement $w$ is referred to as the cohesive stress function $\sigma(w)$. The cohesive stress $\sigma\left(C T O D_{\mathrm{c}}\right)$ at the tip of the initial notch length $a_{0}$ at the critical state can be obtained from the softening curve. In this paper, the exponential softening curve suggested by Reinhardt et al. ${ }^{7}$ was used. The value of $\sigma\left(C T O D_{c}\right)$ was determined using the following formula:

$$
\begin{aligned}
& \sigma\left(C T O D_{\mathrm{c}}\right)=f_{\mathrm{t}}\left\{\left[1+\left(\frac{c_{1} C T O D_{\mathrm{c}}}{w_{\mathrm{c}}}\right)^{3}\right] \exp \left(\frac{-c_{2} C T O D_{\mathrm{c}}}{w_{\mathrm{c}}}\right)\right. \\
& \left.-\frac{C T O D_{\mathrm{c}}}{w_{\mathrm{c}}}\left(1+c_{1}^{3}\right) \exp \left(-c_{2}\right)\right\}
\end{aligned}
$$

where $f_{\mathrm{t}}$ is the tensile strength in $\mathrm{MPa}, C T O D_{\mathrm{c}}$ is the critical crack-tip-opening displacement in $\mathrm{mm}$ (the details regarding the calculation can be found $\mathrm{in}^{4}$ ), $w_{\mathrm{c}}$ is the maximum crack-tip-opening displacement in $\mathrm{mm}$ (in this case $w_{\mathrm{c}}=0.06 \mathrm{~mm}$ for all the specimens), and $c_{1}, c_{2}$ are the material constants (in this case constants $c_{1}=3$ and $c_{2}=6.93$ were considered as recommended $i^{4}$ ).

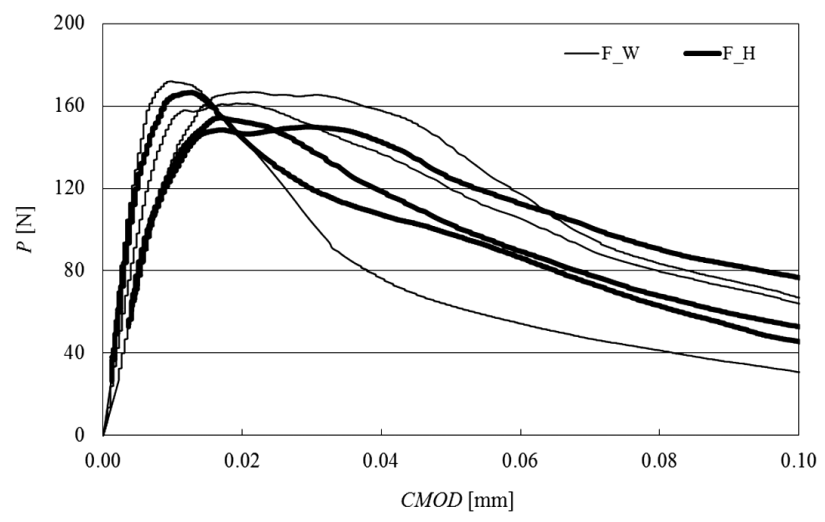

Figure 5: $P-C M O D$ diagrams recorded during testing - the set of specimens with pulverized-coal fly ash $(\mathrm{F})$

Slika 5: Diagrami $P-C M O D$, posneti med preizkušanjem - vrsta vzorcev z elektrofiltrskim pepelom premoga $(\mathrm{F})$

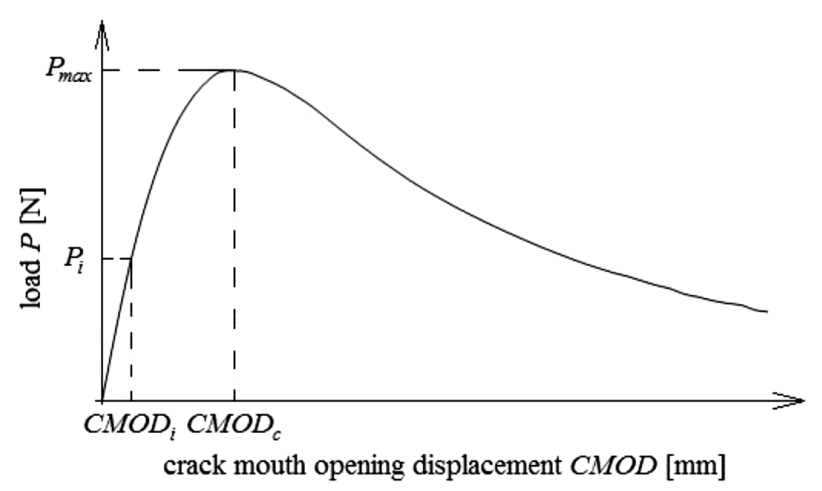

Figure 6: Deduction of the input data for the double- $K$ model from the $P-C M O D$ diagram

Slika 6: Vhodni podatki za model $\mathrm{z}$ dvojnim $K$ iz diagrama $P$ $C M O D$ 
The tensile-strength value was estimated using the measured compressive-strength value suggested by documentation ${ }^{8}$, using the following relationship:

$$
f_{\mathrm{t}}=0.24 f_{\mathrm{cu}}^{2 / 3}
$$

where $f_{\mathrm{cu}}$ is the compressive cube strength in $\mathrm{MPa}$ (in this case these values were estimated from the informative compressive tests on the fragments of the specimens after the fracture tests).

Finally, the value of the load $P_{\text {ini }}$ was determined according to Equation (5). This value can be defined as the load level at the beginning of the stable crack propagation from the initial crack/notch:

$$
P_{\text {ini }}=\frac{4 W K_{\mathrm{Ic}}^{\mathrm{ini}}}{S F_{1}\left(\alpha_{0}\right) \sqrt{a_{0}}}
$$

where $W$ is the section modulus in $\mathrm{m}^{3}$ (determined as $\left.W=1 / 6 B D^{2}\right), K_{\mathrm{Ic}}{ }^{\text {ini }}$ is the initial fracture toughness in $\mathrm{Pa} \mathrm{m}^{1 / 2}, S$ is the span length in $\mathrm{m}, a_{0}$ is the initial notch length in $\mathrm{m}$, and $F_{1}\left(\alpha_{0}\right)$ is the geometry function determined using the following equation ${ }^{9}$ :

$$
F_{1}\left(\alpha_{0}\right)=\frac{1.99-\alpha_{0}\left(1-\alpha_{0}\right)\left(2.15-3.93 \alpha_{0}+2.7 \alpha_{0}^{2}\right)}{\left(1+2 \alpha_{0}\right)\left(1-\alpha_{0}\right)^{3 / 2}}
$$

where $\alpha_{0}$ is ratio $a_{0} / D$.

\section{RESULTS}

The mean values of the selected results are presented in the tables: elasticity modulus $E$ (Table 1), fracture toughness $K_{\mathrm{Ic}}$ un (Table 2), relative resistance to stable crack propagation $K_{\mathrm{Ic}}{ }^{\text {ini }} / K_{\mathrm{Ic}}$ un (Table 3), load level at the beginning of the stable crack propagation from the initial notch $P_{\text {ini }}$ (Table 4) and relative expansion at the age of $16 \mathrm{~d} \varepsilon_{16 \mathrm{~d}}$ which indicates the risk of alkali-silica reactivity (Table 5). The above-mentioned tables also give

Table 1: Mean values of elasticity modulus and their relative values (1.00...R_|1.00..._W)

Tabela 1: Srednje vrednosti modula elastičnosti in njihove relativne vrednosti (1.00...R_|1.00..._W)

\begin{tabular}{|c|c|c|c|c|}
\hline \multirow{2}{*}{$E$} & \multicolumn{2}{|c|}{ W } & \multicolumn{2}{c|}{$\mathrm{H}$} \\
\cline { 2 - 5 } & $\begin{array}{c}\text { mean value } \\
(\mathrm{GPa})(\text { COV/\%) }\end{array}$ & $\begin{array}{c}\text { relative } \\
\text { value }(-)\end{array}$ & $\begin{array}{c}\text { mean value } \\
(\mathrm{GPa})(\text { COV/\% })\end{array}$ & $\begin{array}{c}\text { relative } \\
\text { value }(-)\end{array}$ \\
\hline $\mathrm{R}$ & $27.9(13.7)$ & $1.00 \mid 1.00$ & $18.2(23.0)$ & $1.00 \mid 0.65$ \\
\hline $\mathrm{S}$ & $24.8(32.1)$ & $0.89 \mid 1.00$ & $18.6(30.8)$ & $1.02 \mid 0.75$ \\
\hline $\mathrm{F}$ & $23.5(31.5)$ & $0.84 \mid 1.00$ & $20.8(26.0)$ & $1.14 \mid 0.88$ \\
\hline
\end{tabular}

Table 2: Mean values of fracture toughness and their relative values $(1.00 \ldots$ R_|1.00..._W)

\begin{tabular}{|c|c|c|c|c|}
\hline \multirow[b]{2}{*}{$K_{\mathrm{Ic}}{ }^{\text {un }}$} & \multicolumn{2}{|c|}{ W } & \multicolumn{2}{|l|}{$\mathrm{H}$} \\
\hline & $\begin{array}{c}\text { mean value } \\
\left(\mathrm{MPa} \mathrm{m} \mathrm{m}^{1 / 2}\right) \\
(\mathrm{COV} / \%)\end{array}$ & $\begin{array}{l}\text { relative } \\
\text { value }(-)\end{array}$ & $\begin{array}{c}\text { mean value } \\
(\mathrm{MPa})(\mathrm{COV} / \%)\end{array}$ & $\begin{array}{c}\text { relative } \\
\text { value }(-)\end{array}$ \\
\hline $\mathrm{R}$ & $0.569(4.3)$ & $1.00 \mid 1.00$ & $0.624(9.8)$ & $1.00 \mid 1.10$ \\
\hline $\mathrm{S}$ & $0.606(16.0)$ & $1.06 \mid 1.00$ & $0.613(4.4)$ & $0.98 \mid 1.01$ \\
\hline $\mathrm{F}$ & $0.631(6.2)$ & $1.11 \mid 1.00$ & $0.616(13.1)$ & $0.99 \mid 0.98$ \\
\hline
\end{tabular}

Tabela 2: Srednje vrednosti lomne žilavosti in njihove relativne vrednosti $(1.00 \ldots$ R_|1.00...W $)$ the relative values of these parameters: first in relation to $\mathrm{R}$, then in relation to the specimens cured in $\mathrm{W}$.

Table 3: Mean values of relative resistance to stable crack propagation and their relative values $\left(1.00 \ldots \mathrm{R}_{-} \mid 1.00 \ldots \_\mathrm{W}\right)$

Tabela 3: Srednje vrednosti relativne odpornosti proti stabilnemu napredovanju razpoke in njihove relativne vrednosti $\left(1.00 \ldots R_{-} \mid 1.00 \ldots \_W\right)$

\begin{tabular}{|c|c|c|c|c|}
\hline \multirow{2}{*}{$\begin{array}{c}K_{\mathrm{Ic}}^{\text {ini }} \\
/ K_{\mathrm{Ic}}{ }^{\text {un }}\end{array}$} & $\begin{array}{c}|c| \\
\text { mean value }(-) \\
(C O V / \%)\end{array}$ & $\begin{array}{c}\text { relative } \\
\text { value }(-)\end{array}$ & $\begin{array}{c}\text { mean value }(-) \\
(C O V / \%)\end{array}$ & $\begin{array}{c}\text { relative } \\
\text { value }(-)\end{array}$ \\
\hline $\mathrm{R}$ & $0.542(0.6)$ & $1.00 \mid 1.00$ & $0.340(31.4)$ & $1.00 \mid 0.63$ \\
\hline $\mathrm{S}$ & $0.555(30.0)$ & $1.02 \mid 1.00$ & $0.384(13.2)$ & $1.13 \mid 0.69$ \\
\hline $\mathrm{F}$ & $0.384(8.3)$ & $0.71 \mid 1.00$ & $0.347(14.6)$ & $1.02 \mid 0.90$ \\
\hline
\end{tabular}

Table 4: Mean values of load level at the beginning of stable crack propagation from the initial notch and their relative values $(1.00 \ldots$ R_|1.00..._W)

Tabela 4: Srednje vrednosti obremenitve na začetku rasti razpoke od začetne zareze in njihove relativne vrednosti (1.00...R_|1.00...W)

\begin{tabular}{|c|c|c|c|c|}
\hline \multirow{2}{*}{$P_{\text {ini }}$} & \multicolumn{2}{|c|}{$\mathrm{W}$} & \multicolumn{2}{c|}{$\mathrm{H}$} \\
\cline { 2 - 5 } & $\begin{array}{c}\text { mean value } \\
(\mathrm{N})(C O V / \%)\end{array}$ & $\begin{array}{c}\text { relative } \\
\text { value }(-)\end{array}$ & $\begin{array}{c}\text { mean value } \\
(\mathrm{N})(C O V / \%)\end{array}$ & $\begin{array}{c}\text { relative } \\
\text { value }(-)\end{array}$ \\
\hline $\mathrm{R}$ & $122.2(3.2)$ & $1.00 \mid 1.00$ & $59.7(5.0)$ & $1.00 \mid 0.49$ \\
\hline $\mathrm{S}$ & $127.5(11.7)$ & $1.04 \mid 1.00$ & $93.4(17.4)$ & $1.57 \mid 0.73$ \\
\hline $\mathrm{F}$ & $93.7(2.4)$ & $0.77 \mid 1.00$ & $81.4(2.1)$ & $1.36 \mid 0.87$ \\
\hline
\end{tabular}

Table 5: Mean values of relative expansion at the age of $16 \mathrm{~d}$ and their relative values $\left(1.00 \ldots \mathrm{R}_{-} \mid 1.00 \ldots \_\mathrm{W}\right)$

Tabela 5: Srednje vrednosti relativne ekspanzije pri starosti $16 \mathrm{~d}$ in njihove relativne vrednosti $\left(1.00 \ldots \mathrm{R}_{-} \mid 1.00 \ldots \_\mathrm{W}\right)$

\begin{tabular}{|c|c|c|c|c|}
\hline \multirow{2}{*}{$\varepsilon_{16 \mathrm{~d}}$} & \multicolumn{2}{|c|}{$\mathrm{W}$} & \multicolumn{2}{c|}{$\mathrm{H}$} \\
\cline { 2 - 6 } & $\begin{array}{c}\text { mean value } \\
(\%)(C O V / \%)\end{array}$ & $\begin{array}{c}\text { relative } \\
\text { value }(-)\end{array}$ & $\begin{array}{c}\text { mean value } \\
\%)(C O V / \%)\end{array}$ & $\begin{array}{c}\text { relative } \\
\text { value }(-)\end{array}$ \\
\hline $\mathrm{R}$ & $-0.0041(-)$ & $1.00 \mid 1.00$ & $0.1901(1.1)$ & $1.00 \mid 46.0$ \\
\hline $\mathrm{S}$ & $-0.0018(11.1)$ & $0.44 \mid 1.00$ & $0.1240(2.3)$ & $0.65 \mid 68.9$ \\
\hline $\mathrm{F}$ & $-0.0051(39.4)$ & $1.23 \mid 1.00$ & $0.0988(15.2)$ & $0.52 \mid 19.5$ \\
\hline
\end{tabular}

\section{DISCUSSION}

It was found that the value of $E$, in the case of the specimens cured in $\mathrm{W}$, was reduced by $11 \%$ due to $\mathrm{S}$ and the use of $\mathrm{F}$ reduced this value by $16 \%$ compared to the $\mathrm{R}$ value. In the case of the specimens cured in $\mathrm{H}$, the use of $\mathrm{S}$ had no significant effect on the value of $E$, but the use of $\mathrm{F}$ increased this value by $14 \%$ compared to the $\mathrm{R}$ value. The comparison of both types of specimen curing shows that the specimens cured in $\mathrm{H}$ had the values of $E$ : R lower by $35 \%$, the values of the specimens containing $\mathrm{S}$ were lower by $25 \%$ and the values of the specimen with $\mathrm{F}$ were lower by $12 \%$.

The value of $K_{\mathrm{Ic}}{ }^{\text {un }}$ in the case of the specimens cured in $\mathrm{W}$ was increased by $6 \%$ due to $\mathrm{S}$ and the use of $\mathrm{F}$ increased this value by $11 \%$ compared to the $\mathrm{R}$ value. In the case of the specimens cured in $\mathrm{H}$, the use of $\mathrm{S}$ or $\mathrm{F}$ had no significant effect on the value of $K_{\mathrm{Ic}}{ }^{\text {un }}$ compared to the $\mathrm{R}$ value. The comparison of both types of specimen curing shows that $\mathrm{R}$ cured in $\mathrm{H}$ had higher values of 
$K_{\text {Ic }}{ }^{\text {un }}$ (by $10 \%$ ) and for the specimens with $\mathrm{S}$ or $\mathrm{F}$ this value was almost the same.

The value of the relative resistance to stable crack propagation $\left(R S C P-K_{\mathrm{Ic}}{ }^{\text {ini }} / K_{\mathrm{Ic}}{ }^{\text {un }}\right)$, in the case of the specimens cured in $\mathrm{W}$, was reduced by $29 \%$ due to the use of $\mathrm{F}$, while the use of $\mathrm{S}$ had no significant effect on this resistance compared to the $\mathrm{R}$ value. In the case of the specimens cured in $\mathrm{H}$, the use of $\mathrm{F}$ had no significant effect on $R S C P$, but using $\mathrm{S}$ increased this resistance by $13 \%$ compared to the $\mathrm{R}$ value. The comparison of both types of specimen curing shows that the specimens cured in $\mathrm{H}$ had the RSCP: $\mathrm{R}$ value lower by $37 \%$, the value of the specimen with $\mathrm{S}$ was lower by $31 \%$ and the value of the specimen with $\mathrm{F}$ was lower by $10 \%$.

The value of $P_{\text {ini }}$, in the case of the specimens cured in $\mathrm{W}$, was increased by $4 \%$ due to the use of $\mathrm{S}$ and $\mathrm{F}$ decreased this value by $23 \%$ compared to the $\mathrm{R}$ value. In the case of the specimens cured in $\mathrm{H}$, both $\mathrm{S}$ and $\mathrm{F}$ increased this value: $\mathrm{S}$ by $57 \%$ and $\mathrm{F}$ by $36 \%$ compared to the $\mathrm{R}$ value. The comparison of both types of specimen curing shows that the specimens cured in $\mathrm{H}$ had the values of $P_{\text {ini: }}$ R lower by $51 \%$, the value of the specimen with $\mathrm{S}$ was lower by $27 \%$ and the value of the specimen with $\mathrm{F}$ was lower by $13 \%$.

Further, in the case of the specimens cured in $\mathrm{H}$, it can be assumed, according to the value of $\varepsilon_{16 \mathrm{~d}}$ for R, that the used natural sand can be considered as potentially reactive and dangerous in terms of the volume changes caused by ASR. The value of $\varepsilon_{16 \mathrm{~d}}$ for the specimens with $\mathrm{F}$ was almost half the value for $\mathrm{R}$, namely, approximately $0.10 \%$. This value is the limit, above which the combination of the binder and the aggregates is considered to be potentially dangerous. S was slightly less effective on the suppression of ASR compared to F, but the reduction in the expansion was also quite significant, namely, $35 \%$ compared to R. This observation is in agreement with the work of Thomas ${ }^{10}$. In the case of the specimens cured in $\mathrm{W}$, no significant length changes were observed after the age of $16 \mathrm{~d}$.

When comparing the risk of ASR and the values of $E$ and RSCP for the specimens cured with $\mathrm{W}$ and $\mathrm{H}$, an interesting relationship was noticed: the higher the alkali expansion, the lower were the $E$ and $R S C P$ values for each composite in comparison with the water storage, where the length changes were negligible. The reason can be the stress or even microcrack generation caused by the volume changes resulting from ASR.

\section{CONCLUSIONS}

In this paper, the authors investigated the effect of a mass fraction $20 \%$ replacement of Portland cement, in a fine-grained composite, by granulated blast-furnace slag or pulverized-coal fly ash on the crack initiation (the resistance to stable crack propagation) and volume changes (the risk of alkali-silica reaction). It was observed that both used admixtures can significantly reduce the risk of an alkali-silica reaction, which is important for concrete durability. Fly ash was slightly more effective than slag. If the sodium hydroxide solution was replaced by water, all the composites were dimensionally stable. Further, it was found that the use of slag or fly ash and the type of specimen curing affect the crack initiation. The most resistant composite was the one containing slag and cured in water and the least resistant composite was the reference specimen cured in the sodium hydroxide solution.

\section{Acknowledgement}

This outcome was achieved with the financial support of the junior specific research program at the Brno University of Technology, project No. FAST/FCH-J-142371 .

\section{REFERENCES}

${ }^{1}$ M. Berra, U. Costa, T. Mangialardi, A. E. Paolini, R. Turriziani, Materials and Structures, 46 (2013), 971-985, doi:10.1617/s11527012-9947-6

${ }^{2}$ ASTM International, ASTM C1260-94, 1994, doi:10.1520/C1260-94

${ }^{3}$ ASTM International, ASTM C1567-07, 2007, doi:10.1520/C1567-07

${ }^{4}$ S. Kumar, S. V. Barai, Concrete Fracture Models and Applications, Springer, Berlin 2011, 406, doi:10.1007/978-3-642-16764-5

${ }^{5}$ S. Xu, H. W. Reinhardt, Z. Wu, Y. Zhao, Otto-Graf-Journal, 14 (2003), 131-157

${ }^{6}$ X. Zhang, S. Xu, Engineering Fracture Mechanics, 78 (2011), 2115-2138, doi:10.1016/j.engfracmech.2011.03.014

${ }^{7}$ H. W. Reinhardt, H. A. W. Cornelissen, D. A. Hordijk, Journal of Structural Engineering, 112 (1986), 2462-2477, doi:10.1061/(ASCE) 0733-9445(1986)112:11(2462)

${ }^{8}$ V. Cervenka, L. Jendele, J. Cervenka, ATENA Program documentation - Part 1: theory, Cervenka Consulting, Praha 2012

${ }^{9}$ B. L. Karihaloo, Fracture Mechanics of Concrete, Longman Scientific \& Technical, New York 1995

${ }^{10}$ M. Thomas, Cement and Concrete Research, 41 (2011), 1224-1231, doi:10.1016/j.cemconres.2010.11.003 